\title{
AMOS 7:14: A CASE OF SUBTLE IRONY
}

\author{
Åke Viberg
}

\begin{abstract}
Summary
Amos 7:14 is a key verse for the understanding of Israelite prophecy. Among the unresolved issues relating to this verse is the question whether the nominal clauses should be translated with a present or a past tense. Neither of these alternatives seems to have proved convincing, and therefore we should raise the more fundamental questions as to how the prophet is using language. It is argued that his statement only becomes intelligible when we acknowledge that he is using irony. Amos perceived an ideological gap between his grand vision of YHWH's reign and the reality of his people's situation, and was able to bridge this gap through his use of irony.
\end{abstract}

\section{Introduction}

What was an ancient Israelite prophet, and what did such a person do? These questions have puzzled Old Testament scholars for quite some time, and continue to do so. Were the prophets that we find in the Old Testament always known by the term $n \bar{a} b \hat{\imath}$ ? ? That especially is a question that has been much debated in recent years. Furthermore, in most discussions of the subject, eventually the point is made: did not Amos, after all, deny that he was a prophet? Did he not distance himself from the term $n \bar{a} b \hat{\imath}^{\prime}$ ? It is into this whole complex of difficult issues that I would like to enter by focusing on Amos 7:14, where the prophet does seem to object to being called a $n \bar{a} b \hat{\imath}^{2} .1$

\footnotetext{
${ }^{1}$ The epithet $n \bar{a} b \hat{\imath}^{\prime}$ has recently been found in texts from Meškene, ancient Emar, from the thirteenth century BC, and from Mari from the eighteenth century BC. See D. Fleming, 'Nābû and munabbiātu: Two New Syrian Religious Personnel', JAOS 113 (1993) 175-83; idem, 'The Etymological Origins of the Hebrew nābî': The One Who Invokes God', CBQ 55 (1993) 217-24.
} 
In Amos 7:12-13, Amaziah, the priest of Bethel, orders Amos to leave Bethel and never prophesy there again. This is followed in vv. 14-17 by Amos' reply to Amaziah. According to vv. 10-11, the reason Amaziah gives to king Jeroboam for expelling Amos is his subversive preaching with its predictions of death in battle for Jeroboam and exile for the people of Israel. Taken together, vv. 10-17 in Amos chapter 7 form a dramatic narrative interlude, between the third and fourth of Amos' visions of judgement on Israel. Several questions concerning this interlude have troubled scholars and continue to evade definitive solution, such as the possible redactional history behind its apparent intrusion into the sequence of visions and the meaning and nature of the title $n \bar{a} b \hat{\imath}$ ', 'prophet', as it is used by Amos. However, the most difficult problem has been to understand the tense of the three nominal clauses in v. 14 .

This paper will begin with some introductory questions, then go on to survey the various alternatives currently available for understanding the tense of the nominal clauses in v. 14, and then finally present a new interpretation, based on the proposal that Amos is being ironic in his verbal response to the high priest Amaziah.

\section{History in the Interlude and the Interlude in History}

Although the book of Amos has met with more than its fair share of redaction-critical analyses, no overall consensus has emerged as a result. However, one small part of the book on which scholars of all persuasions tend to agree is the narrative interlude in 7:10-17. It is generally considered that its positioning between the third and fourth of the five visions disturbs the sequence. ${ }^{2}$ It is therefore considered to be an

\footnotetext{
2See H.W. Wolff, Joel and Amos (Philadelphia: Fortress, 1977); H.G.M. Williamson, 'The Prophet and the Plumb-Line. A Redaction-Critical Study of Amos vii' in A.S. Van der Woude (ed.), In Quest of the Past. Studies on Israelite Religion, Literature and Prophetism (OTS 26; Leiden: Brill, 1990) 10123; O. Loretz, 'Die Entstehung des Amos-Buches im Licht der Prophetien aus Mãri, Assur, Ischchali und der Ugarit-Texte. Paradigmenwechsel in der Prophetenbuchforschung', UF 24 (1992) 179-215.
} 
intrusion. ${ }^{3}$ For most scholars, the logical solution to this apparent problem is to postulate an historical development behind the present text, namely that vv. 10-17 were added subsequent to the collection of visions and should in principle be dealt with separately from them. ${ }^{4}$ Other scholars, however, allow for the fact that the narrative and collection of visions could have been created together, with the narrative as an intentional intrusion into and interruption of the flow of the sequence of visions. 5 Standing between these two positions, there is a third and more moderate view that focuses on redaction history. This alternative is chosen by those who are convinced of the secondary character of vv. 10-17, yet still consider it worthwhile to understand precisely why it was placed after the third vision, and how it contributes to our understanding of the collection of visions and, indeed, of the whole book. ${ }^{6}$ This is the alternative that I myself find most

${ }^{3}$ So K. Koch, Amos - Untersucht mit den Methoden einer strukturalen Formgeschichte: Teil 2 Synthese (Neukirchen-Vluyn: Neukirchener, 1976) 49; J. Vermeylen, Du Prophète Isaïe à L'Apocalyptique. Tome II. Isaïe, I-XXXV, miroir d'un demi-millénaire d'expérience religieuse en Israël (Paris: Gabalda, 1978) 565. See also C. Hardmeier, 'Old Testament Exegesis and Linguistic Narrative Research', Poetics 15 (1986) 93, and H. Utzschneider, 'Die Amazjaerzählung (Am 7,10-17) zwischen Literatur und Historie', BN 41 (1988) 84 .

${ }^{4}$ E.g., R.B. Coote, Amos among the Prophets: Composition and Theology (Philadelphia: Fortress, 1981) and J.A. Soggin, The Prophet Amos: $A$ translation and commentary (London: SCM, 1987) both excise the interlude from its position in the text and deal with it at the end of their books. Similarly also G.M. Tucker, 'Prophetic Authenticity: A Form-Critical Study of Amos 7:10-17', Int 27 (1973) 431.

5So L. Eslinger, 'The Education of Amos', HAR 11 (1987) 43; S.M. Paul, Amos: A Commentary on the Book of Amos (Minneapolis: Fortress, 1991) 238, n. 3; Utzschneider, 'Die Amazjaerzählung', 84.

'See Williamson, 'The Prophet and the Plumb-Line', 113-17. Regarding a possible dtr redaction of the book of Amos, W.H. Schmidt ('Die Deuteronomistische Redaktion des Amosbuches', ZAW 77 [1965] 168-93) sees none in Amos 7; Vermeylen, (Du Prophète Isaïe, 565-67) considers 7:9, 16-17 to be dtr; while Loretz ('Die Entstehung', 193) finds dtrP in 7:11, 17. Compare the reasons advanced for the placing of 7:10-17 after the third vision in the analyses of Eslinger, 'The Education', and Williamson, 'The Prophet and the Plumb-Line'. F.I. Andersen, and D.N. Freedman (Amos. $A$ New Translation with Introduction and Commentary [Doubleday: New York, 
convincing, since it leaves the door open to a redaction history as an explanation of the placing of the interlude among the visions. However, once the issue of redaction history is raised, it then becomes relevant to inquire how far the interlude reflects an historical reality, and if it does so in a significant way, to what extent it relates to the historical Amos.

It is still common to consider Amos 7:10-17 as a more or less biographical note, providing us with unique insights into the person and work of the prophet Amos. ${ }^{7}$ Others see it as legendary, ${ }^{8}$ although attributed to Amos himself at a later stage. 9 There is not, however, much that can be used to substantiate such a pessimistic attitude to this section. The narrative does give the impression of presenting an authentic scene from a prophet's life, although it is unique in the sense that the southern prophet has gone to the northern kingdom to prophesy against it. Loretz, in his recent, rather provocative study of the book's composition, at least leaves room for the possibility that 7:9b-10,12-16 might go back to an original clash between Amos and the high priest at Bethel. ${ }^{10}$ Indeed, he holds

1989] 68) take 7:10-17 to be a disciple's eyewitness report of what occurred placed among the visions by an editor.

7See Tucker, 'Prophetic Authenticity', 431 (although with some reservations); J. Blenkinsopp, A History of Prophecy in Israel from the Settlement in the Land to the Hellenistic Period (Philadelphia: Fortress, 1983) 91; R. Rendtorff, Das Alte Testament. Eine Einführung (Neukirchen-Vluyn: Neukirchener, 1983) 232. G. Pfeifer ('Die Ausweisung eines lästigen Ausländers. Amos 7:10-17', ZAW 96 [1984] 112-18) even holds that the interlude was written by Amos. Cf. Utzschneider, 'Die Amazjaerzählung', 76-77, for references to older literature. Utzschneider himself, however, seems to view vv. 10-17 more as a literary creation having intertextual relations to $1 \mathrm{Ki} .13$ (p. 96).

8 So Koch, Amos, 49.

9J.H. Hayes, Amos: The Eighth Century Prophet (Nashville: Abingdon, 1988) considers 7:10-17 to be secondary, the only text in that category besides $1: 1$ that Hayes sees in the book of Amos. Compare Tucker, who, on the basis of its clear edificatory purpose and lack of miracles, denies that Am. 7:1017 can be labelled 'Legendary' ('Prophetic Authenticity', 429). He prefers the genre-label 'story of prophetic conflict'. However, Koch argues against Tucker in favour of the genre 'Legend' (Amos, 49).

10Loretz, 'Die Entstehung', 192-93. This study is a far-ranging attempt to bring about a change of paradigm in the study of the composition of the prophetic books. For the application of various methods to the book of 
that it is in this passage, together with its surrounding visions, that we are likely to find the closest Old Testament parallels to prophecy occurring elsewhere in the ancient Near East.11 The same applies to Fritz in his recent study of a creative, though elusive, 'Amos-school' and its relation to the historical Amos. Fritz considers that very little of the book goes back to the historical Amos (3:12ab $\alpha$; 5:3; 7:1-6), but still regards 7:10-17 as having at least a starting-point in the prophet's experience. It comes as no surprise, however, that Fritz sees 7:14 as a later addition. 12

The possible link between the interlude in Amos 7:10-17 and the historical Amos has, however, been called in question by a comparison with 1 Kings 13, a story often regarded as in some way associated with Amos 7:10-17. Ackroyd explains the similarity between the two texts by postulating a judgement oracle against Jeroboam II, the absence of which from the book of Kings he finds noteworthy. According to Ackroyd, 13 this

Amos and the possibility of paradigm shifts, see F.E. Deist, 'The Prophets: Are We Heading for a Paradigm Shift?' in V. Fritz et al. (eds.), Prophet und Prophetenbuch (Berlin: de Gruyter, 1989) 1-18; G.F. Hasel, Understanding the Book of Amos: Basic Issues in Current Interpretations (Grand Rapids: Baker, 1991) 20-25.

${ }^{11}$ For some recent treatments of prophecy in the ANE, see M. deJong Ellis, 'The Goddess Kititum Speaks to King Ibalpiel: Oracle Texts from Ishchali', MARI 5 (1987) 235-66; idem, 'Observations on Mesopotamian Oracles and Prophetic Texts: Literary and Historiographic Considerations', JCS 41 (1989) 127-86; J.-M. Durand, 'Les Textes Prophetiques', Archives Royales de Mari 26 (Paris: Geuthner, 1988); H.B. Huffmon, 'Prophecy (ANE)', ABD 5 477-82; M. Nissinen, 'Die Relevanz der neuassyrischen Prophetie für die alttestamentliche Forschung' in M. Dietrich and O. Loretz (eds.), Mesopotamica - Ugaritica - Biblica (Alter Orient und Altes Testament 232; Neukirchen-Vluyn: Neukirchener, 1993) 217-58; M. Weippert, 'Aspekte israelitischer Prophetie im Lichte verwandter Erscheinungen des Alten Orients' in G. Mauer and U. Magen (eds.), Ad bene et fideliter seminandum (Alter Orient und Altes Testament 220; Neukirchen-Vluyn: Neukirchener, 1988) 287-319.

${ }^{12} \mathrm{~V}$. Fritz, 'Amosbuch, Amos-Schule und historische Amos' in Prophet und Prophetenbuch 42.

13P.R. Ackroyd, 'A Judgement Narrative between Kings and Chronicles? An Approach to Amos 7:9-17' in G.W. Coats and B.O. Long (eds.), Canon and Authority: Essays in Old Testament Religion and Theology (Philadelphia: Fortress, 1977) 71-87. 
judgement oracle was modified for the book of Amos into an account of a prophet who is in conflict with a priest, and placed among the visions in order to legitimate Amos. In 1 Kings 13, the story is about an 'î̌s 'ělöhîm, 'man of God', i.e., a prophet or prophet-like character, who, at God's command, goes to Bethel to denounce the king Jeroboam I and his illegitimate cult. According to Ackroyd, the original tradition concerning Jeroboam II has here been applied to Jeroboam I. On the basis of this interpretation, there is hardly any room for a historical connection between the prophet Amos and what is described in 7:9-17. The problem is basically how to evaluate the obvious similarities between Amos 7:9-17 and 1 Kings 13, as well as the differences which are just as obvious. Without going into the details of the argument, I side with those scholars who hesitate to see a direct traditio-historical connection between the two stories. ${ }^{14}$ It could well have been Amos 7:10-17 that influenced the similar tradition in 1 Kings 13 rather than the other way round, 15 and so the parallels that do exist would be products of later redactional activity. ${ }^{16}$ There would therefore be no need to postulate the hypothetical 'original anonymous tradition' suggested by Ackroyd. 17

\footnotetext{
${ }^{14}$ See M. Noth, Könige I. Teilband (1-16), (Neukirchen-Vluyn: Neukirchener, 1968) 295. However, according to W. Thiel ('Sprachliche und thematische Gemeinsamkeiten nordisraelitischer Propheten-Überlieferungen', in J. Zmijewski [ed.], Die alttestamentliche Botschaft als Wegweisung [Stuttgart: Verlag Katholisches Bibelwerk, 1990] 362, n. 10) the hypothesis throws no new light either on $1 \mathrm{Ki} .13$ or on Am. 7:10-17.

15See W.E. Lemke, 'The Way of Obedience: 1 Kings 13 and the Structure of the Deuteronomistic History', in F.M. Cross et al. (eds.), Magnalia Dei: The Mighty Acts of God. Essays on the Bible and Archaeology in Memory of G. Ernest Wright (Garden City: Doubleday, 1976) 325, n. 95.

16Williamson ('The Prophet and the Plumb-Line', 119-20) suggests that the same deuteronomic editors may have been behind both Am. 7:9-17 and 1 $\mathrm{Ki}$. 13, thus giving rise to the similarities between the two texts.

17Utzschneider ('Die Amazjaerzählung', 96) prefers to see an intertextual relationship between Am. 7:10-17 and $1 \mathrm{Ki}$. 13, the former deliberately alluding to an earlier version of the latter than the one we have available.
} 


\section{The Problem}

The problem of Amos 7:14 basically resolves itself into two linguistic issues; first, the temporal aspect of its three nominal clauses, and second, the lexical semantics of the two terms used, hōzeh and $n \bar{a} b \hat{\imath}$.

The question of the nominal clauses is formidable enough, and has traditionally been considered the more difficult of the two. However, I believe that this problem is caused not so much by specific features of Amos 7:14 as by a general difficulty in interpreting the linguistic structure of the nominal, or better, verbless, clause in biblical Hebrew. The standard view is that the various possible tenses of a nominal clause are equally probable, but that they can be distinguished on the basis of the context. However, that is not a very satisfying solution. Most frequently, the nominal clause presupposes a present tense, which is why no verbal form is needed on the surface level of the text. ${ }^{18}$ Sometimes, however, a different tense is implied, also without a surface verb-form, but then it is usually indicated in the immediate context by its dependence on a nearby verb. The question for v. 14, therefore, is whether such a connection exists between its nominal clauses and, in particular, the past tense of wayyiqqāhēen $\hat{\imath}$ and wayy $\bar{o}^{\prime} m e r$ in v. 15.

The second problem, that concerning the two terms, is in fact the more difficult. It involves one's view both of ancient Israelite prophecy and of the relationship between the prophets and the cult. However, the problem is also very much a matter of how one reads the text. In v. 12, Amaziah addresses Amos as a hözeh, a term which Amos does not openly reject in his reply.

18See B.K. Waltke, and M. O'Connor, An Introduction to Biblical Hebrew Syntax (Winona Lake: Eisenbrauns, 1990) §4.5c; J. Lyons, Introduction to Theoretical Linguistics (Cambridge: CUP, 1969) 322-23. See also P. Joüon and T. Muraoka, A Grammar of Biblical Hebrew (Engl. rev. ed.; 2 Vols.; Rome: Pontifical Biblical Institute, 1991) 561-64. For recent studies on the nominal clause in Semitics, see R. Contini, Tipologia della frase nominale nel semitico nordoccidentale del 1 millenio A.C. (Studi e ricerche 1; Pisa: Giardini, 1982); D. Cohen, La phrase nominale et l'évolution du système verbal en sémitique (Collection linguistique publiée par la société de linguistique de Paris 73; Leuven/Paris: Peeters, 1984). 
In addition, in vv. 12 and 13, Amaziah tells Amos that he should go back to Judah to 'prophesy' (tinnābes', the verb cognate with nāb $\hat{\imath}^{\nu}$ ) because he is no longer permitted to do so at Bethel. So although the term $n \bar{a} b \hat{l}^{2}$ itself is not used by Amaziah, its cognate verb is. Amos then responds in v. 14 with the three nominal phrases, the first referring to $n \bar{a} b \hat{\imath}^{\prime}$ and the second to the apparently similar ben-nāb $\hat{\imath}^{2}$. Is he thereby rejecting the term $n \bar{a} b \hat{\imath}^{2}$, even though it has not been used by Amaziah? Or was the term $n \bar{a} b \hat{\imath}^{\prime}$ implied by Amaziah's use of hōzeh, or of the verb hinnäbe $\bar{e}^{\jmath}$ ? Or is Amos saying something different altogether? The latter suggestion is indeed the basic contention of this paper. I will start by looking at the text of Amos 7:12-15, and then turn to a survey of earlier interpretations.

\section{The Text of Amos 7:12-15}

${ }^{12}$ Amaziah said to Amos: 'Seer, go! Go back to the land of Judah! There you shall eat your bread, and there you shall prophesy!

${ }^{13}$ But you may not prophesy again at Bethel, because it is the king's sanctuary, the temple of the kingdom.

${ }^{14}$ Then Amos answered Amaziah, saying:

'I am/was not a prophet,

I am/was not even the son of a prophet! wayyo'mer 'ămașyâ 'el-‘āmôs

ḥōzeh lëk bĕrah-lëkä 'el-'ereș

yěhûdâ we'ēkol-šăm leḥem

wěšäm tinnābe $\bar{e}^{\jmath}$

âbêt-'ēl lō's-tôsîp 'ôd lěhinnābe '’ kî miqdaš-melek hâu ûbêt mamlāka hâ

wayya'an ‘āmôs wayyō'mer 'el-'ămașyâ $l \bar{o}^{\prime}-n \bar{a} b \hat{\imath}^{\prime}{ }^{\prime} \bar{a} n \bar{o} k \hat{\imath}$ wĕlō'19 ben-nābî̀'20 'ānōkî

${ }^{19}$ The waw is considered to be epexegetical, more precisely in an emphatic sense: see Waltke and $\mathrm{O}^{\prime}$ Connor, Introduction, \$39.2.4b; see also n. 20 below. Some consider it to be explicative in the sense of making the two phrases substantially synonymous: E. Vogt, 'Waw Explicative in Amos 
I am/was just a herdsman, a dresser of sycamore trees!

${ }^{15}$ But YHWH took me from the flock, and YHWH said to me, "Go and prophesy to my people Israel."' kî̀1-bôqēr 'ānōkî ûbôlēs šiqmîm.

wayyiqqāhēentî22 yhwh mēe ahărê hașșō'n wayyō'mer 'ēlay yhwh lèk hinnābē' 'el-‘ammî yiśrā’ēl

\section{Earlier Interpretations of Amos 7:14}

There have been basically two opposing views of Amos 7:14, neither of which has managed to achieve the status of consensus among scholars. ${ }^{23}$ The two opposing views differ

VII,14', Expository Times 68 (1956-57) 301-02; idem, 'Recensiones', Bib 38 (1957) 472-73; E. Bauman, 'Eine Einzelheit', ZAW 64 (1952) 62. J. Jeremias, Das Buch Amos (Göttingen: Vandenhoeck \& Ruprecht, 1995) 105, n. 2 considers the waw explicative in the sense of specifying the meaning of the first phrase. However, this presupposes that we already know that ben$n \bar{a} b \hat{\imath}{ }^{\prime}$ is a sub-group of the more general term $n \bar{a} b \hat{c} \hat{\imath}^{\prime}$, something which first needs to be shown. Thiel, 'Sprachliche und thematische Gemeinsamkeiten', 360-61, on the other hand, would see two substantially different entities altogether. M. Weiss, The Bible from Within: The Method of Total Interpretation (Jerusalem: Magnes, 1984) 6 makes an unconvincing attempt to see the construction nāb $\hat{\imath}^{2}-b e n-n \bar{a} b \hat{\imath}^{2}$ as idiomatic. Cf. also J.R. Porter, 'Běnē-hanněb̂̂'îm', JTS 32 (1981) 423f.; J.G. Williams, 'The Prophetic "Father": A Brief Explanation of the Term "Sons of the Prophets"', JBL 85 (1966) 344-48.

${ }^{20}$ The pair ben-nāb $\hat{\imath}^{\prime} / n \bar{a} b \hat{\imath}^{2}$ is a form of augmented word pair, built on a pattern that W.G.E. Watson calls "Epithetic word-pairs", $\mathrm{PN}_{1}$ / son of $\mathrm{PN}_{2}$ (Classical Hebrew Poetry: a Guide to its Techniques [JSOTS 26; Sheffield: JSOT Press, 1984] 219, n. 51). There is a good example of this construction in

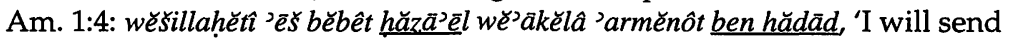
a fire against the house of Hazael, and it will burn the palaces of the son of Hadad.' The same technique is often used in Ugaritic: e.g., KTU(2) 1.14.II:24-26: srd . $\underline{b^{c} l} b d b h k . \underline{b n} . d g n b m s d k$, 'May Baal descend by your sacrifice, the son of Dagan by your game.'

${ }^{21}$ The $k \hat{\imath}$ here is restrictive in relation to the former negative clauses, giving the sense 'Rather, I am...': so, apparently, Waltke and O'Connor, Introduction, $\$ 39, \mathrm{n} .100$.

${ }^{22}$ The waw is adversative: 'But he took me...'.

23For overviews of various interpretative options see: H.H. Rowley, 'Was Amos a Nabi?' in J. Fück (ed.), Festschrift Otto Eissfeldt (Halle: Niemeyer, 
mainly in their temporal understanding of the three nominal clauses:

\author{
14a la lo \\ 14b wĕlō' ben-nābî̀' 'ānōkî \\ 14c kî-bôqēr 'ānōkî abôlēs šiqmîm
}

One view understands them as implying a past tense, whereas the other opts for the present. In fact, other interpretations have been suggested, and they will be summarised below. However, none of these more speculative solutions to the problem have achieved the same popularity among scholars as the two which invoke either a present or a past tense in v. 14.

\title{
1. A present tense
}

To regard the three nominal clauses in Amos 7:14 as indicating the present tense is the simplest and most natural understanding. ${ }^{24}$ The translation would then be: 'I am not a prophet, I am not a son of a prophet, but a herdsman and a tender of sycamore trees. But....' Amos would then be repudiating the view that he was the sort of $n \bar{a} b \hat{\imath}^{\prime}$ that Amaziah was used to dealing with at Bethel, a professional attached to the cultic establishment and earning his daily bread by providing oracles. ${ }^{25}$ Amos claims that his vocation, in contrast, was of a different nature, since $\mathrm{YHWH}$ himself had called him

1947) 191-98; Wolff, Joel and Amos, 312-13; Paul, Amos, 243-47; Hasel, Understanding, 41-47.

${ }^{24}$ So R. Smend, 'Das Nein des Amos', EvT 23 (1963) 416; H. Schmid, "'Nicht Prophet bin ich, noch bin ich Prophetensohn": zur Erklärung von Amos 7,14a', Judaica 23 (1967) 73; W. Rudolph, Joel - Amos - Obadja - Jona (Gütersloh: Gerd Mohn, 1971) 256-57; Wolff, Joel and Amos, 312-13; R.R. Wilson, Prophecy and Society in Ancient Israel (Philadelphia: Fortress, 1980) 269; A. Neher, Amos: Contribution a l'étude du prophétisme (2nd ed.; Paris: Vrin, 1981) 22; F. Landy, 'Vision and Poetic Speech in Amos', HAR 11 (1987) 237; H.J. Stoebe, 'Noch einmal zu Amos VII,10-17', VT 39 (1989) 350; M. Tsevat, 'Amos 7:14 - Present or Preterit?', in M.E. Cohen (ed.), The Tablet and the Scroll (Bethesda: CDL, 1993) 258.

${ }^{25}$ So W.R. Harper, Amos and Hosea (Edinburgh: T. \& T. Clark, 1936) 171; V. Maag, Text, Wortschatz und Begriffswelt des Buches Amos (Leiden: Brill, 1951) 170; Wolff, Joel and Amos, 313; Blenkinsopp, A History, 127, n. 23; J.A. Dearman, Religion and Culture in Ancient Israel (Peabody: Hendrickson, 1992) 157. 
away from his normal work (v. 14c-15). We would therefore have to see the use of $n \bar{a} b \hat{\imath}^{\mathcal{}}$ in Amos' answer as referring to a particular type of prophet which some scholars refer to as 'cultic prophet'. 26

Indeed, the book of Amos has always figured prominently in hypotheses regarding the nature of Old Testament prophets in general, and writing prophets in particular. Beginning with Wellhausen, a clear distinction was drawn between the writing prophets and the nĕbî'îm, the latter being cultic and part of what the Old Testament prophets spoke out against. ${ }^{27}$ Scholars of this persuasion tended to prefer the present tense in Amos 7:14, thus seeing Amos as taking a stand over against such cultic prophets. This distinction was later questioned by scholars who, in contrast, considered Amos' background to be that of the cult, concluding that he was actually a cultic prophet, or at least had been one at an earlier stage. ${ }^{28}$ These scholars tended to prefer the past tense in Amos 7:14, seeing Amos as appropriating the term himself. More recently, the tendency to view Amos and his message in only one context has rightly been questioned, in favour of a more diversified background to the message of the book of Amos, such as the wisdom and legal traditions. ${ }^{29}$

\footnotetext{
${ }^{26}$ Although this has been used to explain why Amos denies the label nābî', it has also been employed with the opposite intention, by scholars who view him as a cultic prophet. See H.G. Reventlow, Das Amt des Propheten bei Amos (FRLANT 80; Göttingen: Vandenhoeck \& Ruprecht, 1962) 21-22. 27J. Wellhausen, Skizzen und Vorarbeiten. Fünftes Heft. Die kleinen Propheten übersetzt mit Noten (Berlin: Georg Reimer, 1892) 89.

${ }^{28}$ According to E. Würthwein ('Amos-Studien', ZAW 62 [1950] 29) Amos began as anstitutionalised $n \bar{a} b \hat{\imath}^{\prime}$, whose message can be found in the first two of the five visions in the book of Amos. He later became a prophet of doom, which made it impossible for him to associate himself with the nĕbî̀îm, hence his rejection of that label in 7:14. Würthwein worked on the assumption that a prophet was either a prophet of salvation, as with the institutionalised něbî̀im, or a prophet of doom. This dichotomy has been challenged by H.J. Gunneweg ('Erwägungen zu Amos 7,14', ZTK 57 [1960] 13) who argues that a nâbî̀ could also have been a messenger of doom and therefore that Amos did not cease being one of the nébî'îm.

${ }^{29}$ See the discussion in Hasel, Understanding, 80-81.
} 
An important argument in favour of the present tense is the use of Amos 7:14 in Zechariah 13:5, where prophets in disguise claim: $l \bar{o}^{\prime}$ nābî' 'ānōkî 'î̌s-‘ōbed 'ădāmâ 'ānōkî, 'I am not a prophet, I am a farmer!' Here the present tense is undoubtedly correct, and this would imply that the author of Zechariah 13:5 understood a present tense in Amos 7:14 as well. Although it is theoretically possible that the author of Zechariah 13:5 could have been mistaken about Amos 7:14, an ancient Judahite would surely have been more familiar with the syntax of his own language than modern scholars, despite Amos 7:14 being several centuries old at the time of writing of Zechariah 13:5.30

On the other hand, the problems with seeing a present tense in Amos 7:14 all centre on how to make sense of the verse in its literary context. In vv. 12-13, Amaziah calls Amos a hōzeh, 'seer' (v. 12), and tells him not to hinnābe $\vec{e}$, 'prophecy' at Bethel (v. 13) but to do so in Judah instead (v. 12). These two statements taken together provide us with some important information:

1) Amaziah's use of the verb hinnāb $\bar{e}^{\supset}$ implies that he considered Amos to be a $n \bar{a} b \hat{\imath}^{\prime}$. It is most likely, that Amos understood it in this way as well, since he counters with the claim that he is not a $n \bar{a} b \hat{\imath}^{2}$.

2) Amaziah therefore regarded hōzeh and $n \bar{a} b \hat{\imath}^{>}$as roughly synonymous.

3) There is no trace in Amaziah's injunction of any distinction between different types of prophets, only between prophets with different intentions, loyalties and messages.

It is also hard to see Amos shifting between two different meanings of $n \bar{a} b \hat{\imath}^{\prime} / h i n n a \bar{a} b \bar{e}^{3}$, one in v. 14, which he denies, and one in v. 15, which he accepts. But this is the cornerstone of the present-tense interpretation, and once the double meaning of $n \bar{a} b \hat{\imath}^{\supset} / h i n n \bar{a} b \vec{e}^{\supset}$ is rejected, so too is the straight-

${ }^{30}$ C.L. Meyers and E.M. Meyers (Zechariah 9-14: A New Translation with Introduction and Commentary [New York: Doubleday, 1993] 380-81) hold that second Zechariah's use of Am. 7:14 follows a discernible pattern by which he 'appeals to or uses traditional materials but never in a slavish way.' Contrast Rowley, 'Was Amos a Nabi?', 192-93. 
forward interpretation of vv. 14-15, since in that case Amos would seem to contradict himself.

\section{A past tense}

The most important argument in favour of a past tense is that then there is no need for a double meaning of $n \bar{a} b \hat{\imath}^{\nu} /$ hinnābe $\bar{e}^{3}{ }^{31}$ On this interpretation, what Amos claims YHWH has called him to do (v. 15) is the very thing Amaziah has tried to stop him doing (v. 13). The semantic distinction, made necessary by the present tense interpretation, is here replaced by a temporal distinction.

A past tense in v. 14 would also seem to fit naturally before v. 15, 'I used not to be a prophet, but YHWH called me, and now I am one.' It also has the support of the LXX, Ovंк $\mu^{\prime} \eta v$

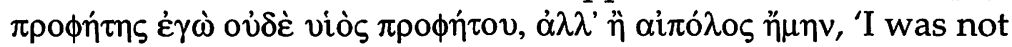
a prophet, nor a son of a prophet, but I was a herdsman'.

However, as was said above, if a past tense is chosen for a nominal clause, it has to be indicated in the literary context. In Amos 7:14, however, it is hard to find any such indications. Moreover, if a past tense were chosen, vv. 14-15 would then read as an autobiographical note by Amos, interrupting the narrative in vv. 10-13 and quite unrelated to what Amaziah has just commanded in vv. 12-13. Furthermore, had Amos intended to say that he had not always been a prophet, he could have done so in a clearer and less ambiguous way than three successive nominal clauses.

\section{Other interpretations}

Some take the first particle $l \bar{o}^{\supset}$ of the first nominal clause as an emphatic negative marker, making it an independent clause

31So Rowley, 'Was Amos a Nabi?', 191-98; A.S. Kapelrud, Central Ideas in Amos (Oslo: Aschehoug, 1956) 7; Reventlow, Das Amt des Propheten, 20; R.E. Clements, Prophecy and Covenant (SBT 43; London: SCM, 1965) 36-37; S. Amsler, Amos in E. Jacob, C.-A. Keller, S. Amsler, Osée, Joël, Abdias, Jonas, Amos (Paris: Delachaux \& Niestlê, 1965) 230-31; J.L. Mays, Amos: $A$ Commentary (London: SCM, 1969) 138-39; Tucker, 'Prophetic Authenticity', 432; Coote, Amos, 93; R. Martin-Achard, Amos: L'homme, le message, l'influence (Geneva: Labor et Fides, 1984) 29-30; Soggin, The Prophet Amos, 128; Andersen and Freedman, Amos, 778; Hasel, Understanding, 47; Paul, Amos, 247; Jeremias, Amos, 109-10. 
'No! I am a $n \bar{a} b \hat{\imath}$ ', I am not even a ben-nāb $\hat{\imath}^{\prime}$. This would mean something like 'No! (I am not a hōzeh, dependent on the king's favour,) I am a $n \bar{a} b \hat{\imath}^{\prime}$, (an independent prophet), and neither am I the disciple of a prophet (i.e., under his authority).'32 However, it is unlikely that this is a natural interpretation according to Biblical Hebrew syntax. ${ }^{33}$ Furthermore, why should the two instances of $l \bar{o}^{>}$not be the same in their relation to what follows them?

Others take the first $l \bar{o}^{\prime}$ as an asseverative particle, related to the emphatic lamed. ${ }^{34}$ However, that would again mean that the two occurrences of $l \bar{o}^{\prime}$ in very similar adjacent clauses are nevertheless different, something which seems unlikely.

The first $l \tilde{o}^{\prime}$ has also been taken as an interrogative particle, equivalent to the more usual hălö’.35 The translation would then be: 'Am I not a prophet and am I not a prophet's son?' However, this translation would not suit the following $\mathrm{v}$. 15. It is not an acceptance of the fact that Amos is a $n \bar{a} b \hat{\imath}^{>}$that we should expect, but the very opposite.

Yet another attempt to come to terms with Amos 7:14 is by postulating that one or more additions have been made to the text, thus giving rise to its present inherent difficulties. Loretz suggests that hozzeh in v. 12 was added later under the

32So Z. Zevit, 'A Misunderstanding at Bethel - Amos VII 12-17', VT 25 (1975) 783-90; S. Cohen, 'Amos was a Navi', HUCA 32 (1961) 175-78; Z. Zevit, 'Expressing Denial in Biblical Hebrew and Mishnaic Hebrew and in Amos', VT 29 (1979) 505-09; S.N. Rosenbaum, Amos of Israel: A New Interpretation (Macon: Mercer UP, 1990).

${ }^{33}$ See Y. Hoffman, 'Did Amos Regard Himself as a Nabi?', VT 27 (1977) 209-12.

34So H.N. Richardson, 'A Critical Note on Amos 7:14', JBL 85 (1966) 89; J. Crenshaw, Prophetic Conflict. Its Effect Upon Israelite Religion (BZAW 124; Berlin: de Gruyter, 1971) 67.

35So G.R. Driver, 'Affirmation by Exclamatory Negation', JANESCU 5 (1973) 107-08; idem, 'Amos 7:14', Expository Times 67 (1955-56) 91-92; idem, 'Waw Explicative in Amos VII,14', Expository Times 68 (1956-57) 302; P.R. Ackroyd, 'Amos 7:14', Expository Times 68 (1956-57) 94; idem, 'A Judgment Narrative between Kings and Chronicles? An Approach to Amos 7:9-17', in G.W. Coats and B.O. Long (eds.), Canon and Authority: Essays in Old Testament Religion and Theology (Philadelphia: Fortress, 1977) 83. 
influence of the use of the verb hăza in 1:1, and thus solves the problem of why two terms are used in vv. 12-15. He also considers v. $14 \mathrm{~b}$ to be a so-called ' $k \hat{\imath}$-gloss', thereby explaining why Amos reflects on his background in his answer to Amaziah. However, the lack of any clear indications of redactional activity in the form of additions, the fact that only few scholars consider such a drastic measure necessary to understand the text, and the availability of several more or less plausible interpretations of the present text makes recourse to textual emendation unnecessary.

A quite different interpretation has been suggested by Bach, who proposes that the nominal clauses in v. 14 are dependent on the following verbal clause in v. 15 and thus have the same past tense. ${ }^{36}$ He therefore translates vv. $14-15$ as follows: 'Although I was not a prophet, or belonged to a group of prophets... YHWH took me...'. Bach has thereby read the nominal clauses as subordinated to the following verbal clause in a contrastive, or concessive manner by taking them as circumstantial clauses. ${ }^{37}$ It follows from this reading that the text does not say anything about whether Amos only considered himself to be a $n \bar{a} b \hat{\imath}^{\jmath}$ after YHWH had called him, or whether, in his own eyes, he ever became one at all. 38

The main problem with this interpretation is not necessarily the order of the clauses, although it would seem that the subordinate clause normally follows the main one. ${ }^{39}$

36R. Bach 'Erwägungen zu Amos 7, 14', in J. Jeremias, and L. Perlitt (eds.), Die Botschaft und die Boten (Neukirchen-Vluyn: Neukirchener, 1981) 203-16. This interpretation has been accepted by Loretz ('Die Entstehung', 192) and Jeremias (Amos, 105, n. 1, 109-10).

37For concessive clauses made up of circumstantial clauses, see R.J. Williams, Hebrew Syntax: An Outline (2nd ed.; Toronto: University of Toronto Press, 1976) §528-32; Joüon and Muraoka, (Grammar, §171) convincingly relate the concessive notion to that of contrast, whereas Waltke and $\mathrm{O}^{\prime}$ Connor (Introduction, $\S 38, \mathrm{n}$. 18) prefer not to use the category 'concessive' but to see it as part of the larger class of conditional clauses.

38Jeremias, however, who sides with Bach, also considers the past tense to be the most suitable (Amos, 109-10).

${ }^{39}$ Waltke and O'Connor, Introduction, $\$ 39.2 .3 \mathrm{~b}$ seem to presuppose the order 'subordinate clause - main clause'. For an exception which is not quite relevant in this case, see Joüon, and Muraoka, Grammar, §159f. I have 
Rather it is that the subordinate clause usually requires an initial waw to indicate the subordination. ${ }^{40} \mathrm{~A}$ possible reason for this lack of a waw is that the conjunction is less common in direct discourse, such as Amos 7:14 (see also, e.g., Ps 39:2).41 There is, however, nothing on the surface of the text of Amos 7:14 that would indicate a subordination of the nominal clauses, and this in itself makes a subordinative construction less likely. Neither is there anything in the content of the text that would indicate the necessity of subordinating the nominal clauses. On the contrary, it would seem unlikely since the first two nominal clauses are introduced by the negative particle $l \bar{o}^{\prime}$ and not by 'ên, the negative particle usually found in nominal clauses. 42 The particle $l \vec{o}^{3}$ is different in that it more forcefully negates the predicate which, in the case of Amos 7:14, is the noun $n \bar{a} b \hat{\imath}^{\supset} .43$ This added emphasis indicates that the nominal clauses are independent of any nearby verbal ones. Thus, since the nominal clauses come prior to the verbal clause to which they are supposed to be subordinated but are not introduced by the conjunction waw to indicate such subordination, and since the negation $l \bar{o}^{\prime}$ has been chosen to negate the term nāb $\hat{\imath}^{\prime}$ more emphatically, it would seem natural to view them as independent of the verbal clause in v. 15. Their main function, therefore, is to negate the claim that Amos is/was a nāb $\hat{\imath}^{2}$.

not found any examples of contrastive/concessive circumstantial clauses that precedes the main clause.

40See Joüon and Muraoka, Grammar, §172f; Waltke and O'Connor, Introduction, $\$ 39.2 .3$. This cannot be made into an absolute rule, however, since there are examples of an asyndetic variant (e.g., Gn. 12:8; 24:22): see F.I. Andersen, The Sentence in Biblical Hebrew (Janua Linguarum. Series Practica 231; The Hague: Mouton, 1974) §3.10.5.

41Andersen, The Sentence, §3.1. It should be noted, however, that here Andersen is discussing the surface level of appositional constructions. The opposite can also be found, e.g., Gn. 18:27: hô'altî lédabbër 'el-'ădōnāy

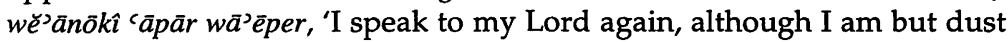
and ashes.'

42See GK §152a, d; Joüon and Muraoka, Grammar, §160b, g.

${ }^{43}$ See Joüon and Muraoka, Grammar, \$160c: 'Generally speaking, ' al before a nominal predicate... negates the latter more forcefully than 'ên would do.' 
Watts has suggested that the syntactical problem is one of mood instead of tense. ${ }^{44}$ The translation would then be: 'No prophet did I choose to be! (I did not choose or seek the status of $\left.n \bar{a} b \hat{\imath}^{\jmath}\right)$. Nor did I seek to become one of the prophetic guild. For $I$ (had chosen to be) a herdsman and a tender of sycamores, when $Y H W H$ took me from following the flock (the place of my choice)...'. Although it is hard to falsify such an interpretation, I cannot, on the other hand, find any clues that would indicate that Watts is correct. And even though Watts emphasises the modal aspect, his interpretation is very close to the past tense understanding.

\section{A New Interpretation: A Case of Subtle Irony}

Since no significant distinction can be made between $n \bar{a} b \hat{\imath}^{\supset}$ and hözeh, no present tense can be supported in v. 14, as argued above. We also found it unlikely that three independent nominal clauses bearing such emphasis would imply a past tense. The next alternative in our search for a satisfying interpretation of Amos 7:14 is that Amos is not saying what appears at first glance to be his meaning. If Amos did not actually mean what he appears to be saying, the best alternative is to see the statement as an example of irony, since the pejorative aspect of irony is eminently suitable in the dispute with Amaziah. ${ }^{45}$ Abrams has a useful definition of irony:

44J.D.W. Watts, Vision and Prophecy in Amos (Leiden: Brill, 1958) 12. Watts describes this mood as 'a kind of subjunctive of volition.'

45Irony is well-known in the literature from the ancient Near East: e.g., KTU(2) 1.6.II:9-11. The goddess Anat grasps the hem of Mot's mantle in order to make a request for her brother's freedom. Later it is said in lines 30-31 that tihd bn . ilm . mt, 'She (Anat) grasped Mot, the son of $\mathrm{El}^{\prime}$, and slaughtered him. The irony resides in the use of the verb ahd in the form tibd in both cases. That the two acts are intended to be parallel is made clear by the fact that they are both preceded by three lines describing Anat's longing for her brother. Compare also the apparent irony in $1 \mathrm{Sa}$. 15:27, where Saul's act of submission and supplication turns into an act of defiance, as if by accident. For studies on irony in the Old Testament, see S.H. Blank, 'Irony by Way of Attributions', Semitics 1 (1970) 1-6; P.F. Jacobs, "Cows of Bashan" - A Note on the Interpretation of Amos 4:1', JBL 104 (1985) 109-10; L.R. Klein, The Triumph of Irony in the Book of Judges 
Verbal irony is a statement in which the meaning that a speaker implies differs sharply from the meaning that is ostensibly expressed. The ironic statement usually involves the explicit expression of one attitude or evaluation, but with indications in the overall speech-situation that the speaker intends a very different, and often opposite, attitude or evaluation. 46

In the following, I will refer to verbal irony simply as irony, and specify when another kind is intended. My grounds for suggesting that irony is present in Amos 7:14 are as follows.

The use of Amos 7:14 in Zechariah 13:5 has not received the emphasis that it deserves. However, Zechariah 13:5 is the earliest inter-textual understanding of Amos 7:14 that we have, and deserves to be considered as such. The fact that Zechariah 13:5 virtually quotes Amos 7:14a and definitely has a present tense, implies that the past tense interpretation of Amos 7:14 is not as likely as so many would believe. However, Zechariah 13:5 is relevant not only because it has a present tense, but also because it appears to contain some ironic nuances as well.

Irony is already a well-known phenomenon in the book of Amos. The best example is of course the irony in the composition of the oracles against the foreign nations in Amos 1:3-2:16.47 If we posit Israel as the implied audience, they would undoubtedly have been pleased at the harsh messages received by the surrounding peoples. And when Judah also received her fair share of the divine anger (2:4-5), Israel's inhabitants would have been delighted, anticipating their own exemption from condemnation. But, unexpectedly, Amos saves them to the last, and they receive his longest and harshest accusations. The

(JSOTS 68: Sheffield: Sheffield Academic Press, 1988); T. Jemielity, Satire and the Hebrew Prophets (Louisville: Westminster, 1992); E.M. Good, Irony in the Old Testament (Philadelphia: Westminster, 1965); J.G. Williams, 'Irony and Lament: Clues to Prophetic Consciousness', Semeia 8 (1977) 5174; idem, 'Comedy, Irony, Intercession: A Few Notes in Response', Semeia 7 (1977) 135-45.

46M.H. Abrams, A Glossary of Literary Terms (6th ed.; Fort Worth: Harcourt Brace Jovanovich, 1993) 97. See also Jemielity's useful description of irony (Satire, 110).

47See Good (Irony, 34) who also notes the use of the geographical progression of the oracles from the periphery to the centre. 
structural device of saving Israel to the end and thereby nourishing the hope that she would be left out altogether was, it turns out, only meant as an ironical means of emphasising their huge sin and blame. 48

In 3:2a, Amos has YHWH say that he has selected Israel from all the families on the earth, intending his hearers to associate this statement with the common view of YHWH's election of his people as an act of salvation and deliverance. However, he then goes on in v. $2 b$ to say that the election was for punishment, and not salvation, thus turning Israelite expectation on its head. In this second statement, the author provides the reader with a sure foundation upon which to identify and interpret the ironic nature of the first one. Such a literary device can be termed 'stable irony'. The opposite is then 'unstable irony', where no such firm position can be found in the surrounding context, and so the interpretation naturally becomes much harder.

In Amos 3:12, YHWH forecasts that just as a shepherd manages to save (yașsill) only some bone fragments or a piece of a sheep's ear from the mouth of a lion (i.e., he fails to save it), so also will Israel be saved (yinnāsẹelua) i.e., fail to be saved. The whole point of the irony is that Israel will face judgement and destruction instead of real salvation. The comparison with the shepherd serves to secure for the reader the verbal irony in the use of the verb nassal, 'save', and so this also is a case of stable irony. A similar case may be found in Amos 9:4, where YHWH says, 'I will fix my eyes on them for harm and not for good'. Here, the phrase sîm 'ênî, 'fix my eyes', might well imply approval and setting aside for some good purpose, an implication which is used for ironic purposes.

In Amos 4:1, the prophet speaks to the cows of Bashan on the mount of Samaria, but subsequently makes it clear that he is actually addressing those wealthy women who oppress the poor, again a case of stable irony. Since irony is based on the incompatibility of two items, its force can be increased by emphasising the incompatibility. The simplest way, and the one

48Paul, however, prefers to speak of the 'final surprise indictment against Israel' $^{\prime}$ Amos, 76). 
utilised here in Amos 4:1, is to employ metaphor to bring together two otherwise completely different items, such as 'cow' and 'woman', with a possible allusion as well to the calf worship in Samaria.49 Metaphor is therefore a possible component of irony, in order to emphasise its ironic force.

In Amos 4:4-5, the prophet continues to use irony against the immoral behaviour of the people of Israel by having YHWH give the following invitation:

Come to Bethel- and transgress; to Gilgal- and multiply transgression; bring your sacrifices every morning, your tithes every three days; bring a thank-offering of leavened bread, and proclaim freewill offerings, publish them; for so you love to do, O people of Israel! says the Lord YHWH.

In Amos 5:18-20, the prophet reverses the ideas commonly associated with the day of $\mathrm{YHWH}$, a concept usually connected with salvation. Here, however, Amos insists that the day of YHWH is darkness, not light! The scene depicted in v. 19 is a most bitter example of dramatic irony. A man manages to flee from a lion, a remarkable achievement in itself, only to come upon a bear! Somehow he escapes the bear as well, comes home and rests his hand against the wall, only to be bitten by a snake. The point of the irony is clear; just as he thought he was safe, he was lost.

In Amos 6:1, woe is proclaimed against those who are

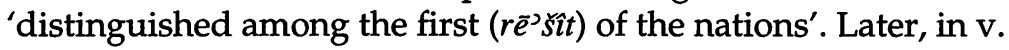

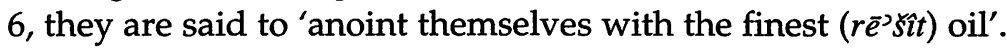
However, this apparent recognition of their supreme rank is shown to be ironic by v. 7, where they are said to go into exile

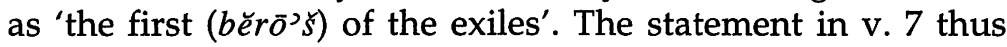
serves to secure the ironic nature of the earlier use of $r \bar{o}^{\prime} \breve{s}$, 'beginning'. It therefore constitutes yet another case of stable irony in the book of Amos, this time based on a paronomastic technique.

These examples show clearly how thoroughly irony in its various forms is put to use in the book of Amos, and how integral it is to its argument.

${ }^{49}$ See Jacobs, “'Cows of Bashan"', 195-99. 
A further argument is based on the nature of irony itself. In his four-fold classification of various forms of irony, Muecke names one category a 'self-disparaging irony':

Into [self-disparaging irony]... there enters... the character and personality of the speaker or writer. The ironist is present not simply as an impersonal voice but, in disguise, as a person with certain characteristics. And the sort of person the ironist presents himself as being is our guide to his real opinion. 50

There are basically two forms of self-disparaging irony, one where the speaker overstates himself, and the other where he understates himself. What we have in Amos 7:14 is a case of understating, in which Amos claims to be less than he actually is in order to reveal the arrogance of the object of his irony, i.e., Amaziah.

The three nominal clauses in v. 14 form an example of pretended self-abasement by Amos, in which he claims to the mighty priest at Bethel to be totally insignificant. 'I am certainly not a $n \bar{a} b \hat{\imath}$ '! No, I am just a simple worker! You, the priest at Bethel, have totally overestimated my humble status!' The necessary catalyst for this irony is Amaziah's use of the verb hinna $\bar{a} b \vec{e}^{\prime}$ in vv. 12-13, and I would also suggest his reference to Amos as a hōzeh. When Amaziah tried to censor Amos and control him as he probably used to control the (cultic?) prophets at Bethel, he was reminded of YHWH's calling and could not resist playing a little game with Amaziah. 51 'What you are so afraid of, Amaziah, is nothing more than a simple worker from Tekoah in Judah!'52 Through his irony, Amos

50D. Muecke, The Compass of Irony (London: Methuen, 1969) 87. F. GarcíaTreto ('A Reader-Response Approach To Prophetic Conflict: The Case of Amos 7.10-17' in J.C. Exum and D.J.A. Clines (eds.), The New Literary Criticism and the Hebrew Bible [JSOTS 143; Sheffield: JSOT Press, 1993] 122) has made a similar analysis of Am. 7:14, although without categorising it as irony.

${ }^{51}$ In Greek comedy the character called the eiron deliberately pretended to be less intelligent than he was. He triumphed over the alazon, who was self-deceiving and stupid. Amos would fit the role of the eiron very well, and Amaziah that of the alazon.

${ }^{52} \mathrm{~T}$. Giles, however, goes too far in claiming that Amos denies any links with a prophetic guild but rather associates himself with the oppressed by 
makes himself into someone quite insignificant, in order to highlight YHWH's role in directing him away from tending to livestock to carrying out the work of one of his prophets, 'But the LORD took me from the flock, and the LORD said to me, "Go and prophesy to my people Israel"' (v. 15).53 In this statement, Amos has stopped using irony and now resorts to more direct discourse. Making use of the contrast created by the irony in v. 14, he emphasises that his status as a prophet owes nothing to man, and therefore he is not subject to any form of institution such as the cult at Bethel, only to the command of YHWH. Amos is indeed a prophet, a $n \bar{a} b \hat{\imath}^{2}$, but that is not the issue; the important question is who has made him a prophet, who has commissioned him and who legitimates his message.

The ironic nature of v. 14 is also obvious from reading through the book of Amos as a whole. It could not have come from someone who was a mere 'tender of sycamore trees', not even if we adopt a minimalist position and consider only those parts agreed by most scholars to derive from Amos himself. Rather, Amos must have received instruction in literary techniques at some form of scribal school in the south. This does not mean that the description of his past is fictional, since he may well have had that profession, 54 but the emphasis on his being nothing but a herdsman is the centre of the understatement. It just cannot be true that he is the simple worker he portrays himself as in v. 14, and so the tenor of the whole book speaks against taking the statement literally. This interpretation of the text therefore also provides a solution to the old problem of accounting both for the book's literary quality, which implies some advanced schooling on Amos' part, and for his claim to have been a shepherd and tender of sycamore trees.

The irony in v. 14 also reveals that when Amaziah banished Amos from Bethel, he not only denied him the permission to preach there, but more importantly he also

stating his profession ('A Note on the Vocation of Amos in 7:14', JBL 111 [1992] 690-92).

53See García-Treto, 'A Reader-Response Approach', 122, for a similar approach.

${ }^{54}$ What Amos' profession actually was is another old crux in Amos: see Hasel, Understanding, 29-40. 
denied YHWH's word access to a shrine where he was in all probability worshipped as the prime deity. Amaziah thought that the matter was solely between himself and Amos, but by means of his irony Amos made it clear that the conflict was not between the priest and the prophet, but between Amaziah and YHWH: the issue at stake was nothing less than the value and authority of YHWH's prophetic message at Bethel.55

\section{Conclusion}

Why was irony so suitable for the Old Testament prophets in general, and for Amos in particular?56 The pre-exilic prophet especially found himself confronting an ideological gap, between on the one hand, his vision of YHWH's reign over his people and how that was to be accomplished, and on the other hand, the reality of the people's actual condition. The two were often felt to be totally incompatible, even to the extent that the prophet sometimes felt it useless to preach to an audience who were so far away from what their God had intended them to be. 57 One way for the pre-exilic prophet to bridge the gap between vision and reality was through the use of irony, based as it is on the opposition of different attitudes, opinions, and ideologies. ${ }^{58}$ By appearing to side with the unfaithful people,

55See A.J. Bjørndalen, 'Erwägungen zur Zukunft des Amazja und Israels nach der Überlieferung Amos 7:10-17' in R. Albertz et al. (eds.), Werden und Wirken des Alten Testament (Neukirchen-Vluyn: Neukirchener, 1980) 242-43; Williamson, 'The Prophet and the Plumb-Line', 117. Regarding the text's intention to authenticate Amos' words, see Tucker, 'Prophetic Authenticity', 433-34.

${ }^{56} \mathrm{By}$ this I do not mean that Amos was necessarily behind everything in the book that bears his name. However, it is highly likely that the historical interlude in 7:10-17 is a reliable witness to the encounter between Amos and the priest Amaziah, together with the instances of irony listed here.

57Indeed, the same explanation could be used to account for the development of the apocalyptic genre from later post-exilic prophecy, since those prophets also perceived an ideological gap between what they believed and preached and the reality which they addressed. It might be fruitful to analyse the apocalyptic genre for instances of irony.

${ }^{58} \mathrm{Klein}$ (The Triumph of Irony, 195) is quite correct in emphasising against Good (Irony, 14) that irony does not originate in conflict but in opposition. 
the prophet would have gained his readers' (or hearers') attention, only to make them realise subsequently that he was actually intending the opposite. Moreover, irony provided him with the opportunity to use certain concepts, words, ideas and expressions unavailable to him had he expressed his own view in a non-ironic manner. In the latter case, the gulf would still have been before him, and he would have had to content himself with preaching across the divide between himself and his people. The use of irony, however, is subtle, and provides a means for the prophet to bridge the gap between himself and his audience, briefly taking their side with the help of their ideology, only to puncture their complacency with the realistic if unpalatable word of YHWH. 59

The relationship between Amaziah and Amos could well be characterised as a conflict, but the irony used by Amos is only a means used by him to clarify and sharpen that conflict.

${ }^{59} \mathrm{~A}$ similar function is performed by metaphor, as shown in my study of Mal. 1:11, 'Awakening the Sleeping Metaphor: A New Interpretation of Malachi 1:11', TB 45 (1994) 297-319. In order to criticise the priests, Malachi starts from the cultic world-view familiar to them, and from there develops his criticism of them by means of metaphor. 